\title{
Correction to: How to model and prove hybrid systems with KeYmaera: a tutorial on safety
}

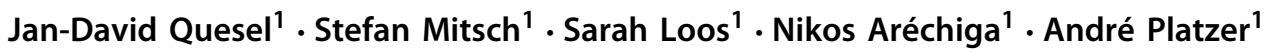

Published online: 1 October 2021

(c) The Author(s) 2021

\section{Correction to: \\ Int J Softw Tools Technol Transfer (2016) 18:67-91 https://doi.org/10.1007/s10009-015-0367-0}

The article How to model and prove hybrid systems with KeYmaera: a tutorial on safety, written by Jan-David Quesel, Stefan Mitsch, Sarah Loos, Nikos Aréchiga and André Platzer, was originally published Online First without Open Access. After publication in volume 18, issue 1, pages 67-91 the author decided to opt for Open Choice and to make the article an Open Access publication. Therefore, the copyright of the article has been changed to The Author(s) 2021 and the article is forthwith distributed under the terms of the Creative Commons Attribution Attribution 4. 0 International License, which permits use, sharing, adaptation, distribution and reproduction in any medium or format, as long as you give appropriate credit to the original author(s) and the source, provide a link to the Creative Commons licence, and indicate if changes were made. The images or other third party material in this article are included in the article's Creative Commons licence, unless indicated otherwise in a credit line to the material. If material is not included in the article's Creative Commons licence and your intended use is not permitted by statutory regulation or exceeds the permitted use, you will need to obtain permission directly from the

The original article can be found online at https://doi.org/10.1007/s10 009-015-0367-0.

\footnotetext{
Jan-David Quesel

jquesel@cs.cmu.edu

$凶$ Stefan Mitsch

smitsch@cs.cmu.edu

$\bowtie$ Sarah Loos

sloos@cs.cmu.edu

Nikos Aréchiga

narechiga@ece.cmu.edu

$\bowtie$ André Platzer

aplatzer@cs.cmu.edu

1 Carnegie Mellon University, Pittsburgh, PA, USA
}

copyright holder. To view a copy of this licence, visit http:// creativecommons.org/licenses/by/4.0.

Publisher's Note Springer Nature remains neutral with regard to jurisdictional claims in published maps and institutional affiliations. 